\title{
Beetroot (Beta vulgaris) Juice Inhibits Key Carbohydrate Metabolising Enzymes Associated With Type II Diabetes
}

\author{
${ }^{1}$ H. A. Oboh, 10. A. Obayiuwana, ${ }^{* 2 E}$. O. Aihie, ${ }^{1} \mathrm{~J}$. I. lyayi and ${ }^{1} \mathrm{E}$. J. Udoh \\ 'Department of Medical Biochemistry, School of Basic Medical Sciences, College of Medical Sciences, University of Benin, Benin \\ City, Edo State, Nigeria \\ ${ }^{2}$ Department of Physiology, School of Basic Medical Sciences, College of Medical Sciences, University of Benin, Benin City, Edo \\ State, Nigeria \\ [Corresponding Author: E-mail: eghe.aihie@uniben.edu; ㄹ: +2348082887154]

\begin{abstract}
Beetroot (Beta vulgaris) is a root tuber belonging to the Amaranthaceae family, which has recently become popular in Nigeria. The reddish purplish tuber and green leaves are usually eaten by boiling, roasting and the raw tuber can be made into juice. This study was carried out to investigate the in vitro ability of aqueous freeze-dried beetroot juice to inhibit a-amylase and a-glucosidase linked to type 2 diabetes (T2D) by spectrophotometric methods. The percentage inhibition and its half maximal inhibitory concentration $\left(\mathrm{IC}_{50}\right)$ of a-amylase and a-glucosidase by beetroot juice with starch revealed that beetroot juice inhibited $a$-amylase $\left(26 \%-73 \% ; \mathrm{IC}_{50}=1.78 \pm 0.13 \mathrm{mg} / \mathrm{mL}\right)$ and $\alpha$-glucosidase $\left(53 \%-85 \% ; \mathrm{C}_{50}=\right.$ $0.77 \pm 0.14 \mathrm{mg} / \mathrm{mL}$ ) in a dose dependent manner. This was compared with the positive control acarbose which inhibited a-amylase $\left(\mathrm{IC}_{50}=0.18 \pm 0.02 \mathrm{mg} / \mathrm{mL}\right)$ and $\mathrm{a}$-glucosidase $\left(\mathrm{IC}_{50}=0.22 \pm 0.01\right.$ $\mathrm{mg} / \mathrm{mL}$ ). Beetroot juice may possess hypoglycemic effects and through these inhibitory mechanisms, it could be used as an adjuvant in the management of hyperglycemia and diabetes.
\end{abstract}

Keywords: Beetroot juice, carbohydrate hydrolyzing enzymes, a-amylase, a-glucosidase.

\section{INTRODUCTION}

Beet (Beta vulgaris) is a root vegetable plant which belongs to the Amaranthaceae family. The plant is commonly grown in Jos, Northern Nigeria. Though not an indigenous plant, it is however gradually being introduced as a component of salad and as constituents of some fruit drinks. The bulbous root tuber of beetroots can be peeled and boiled, or the raw bulb processed into a pink-purplish juice. Beetroot juice is not usually consumed as other fruit and vegetable juices like tomatoes, carrot, apple, mango (Thakur and Das Gupta, 2006). The leaves and roots of beetroot are high in Vitamin A and C (Lintas, 1992) and essential minerals (Olumese and Oboh, 2016a). The plant is rich in protein and fibre (Ansari et al., 2017). Beetroot has a medium glycemic index of 64 (Wootton-Beard et al., 2014).

Beetroot is rich in bioactive compounds, phytochemicals and pharmacotherapeutic agents (Chawla et al., 2015; Odoh and Okoro, 2013) and antioxidants containing polyphenols and flavonoids that are effective free radical scavengers (Georgiev et al., 2010; Olumese and Oboh, 2016b). It can therefore be used as a functional food because it contains pigments called betalains, a class of betalamic acid composed of betacyanins and betaxanthins that are rich in polyphenols and anthocyanins (Pitalua et al., 2010). These bioactive compounds have been reported to reduce both postprandial hyperglycaemia and prevent hyperinsulinaemia by reducing the digestion, absorption and transport of glucose (Bahadoran et al., 2013; Dragan et al., 2015) with a corresponding stimulation of insulin release (Vinayagam et al., 2016). Beetroot juice have also been shown to lower blood glucose level with a concomitant decrease in serum insulin and C-peptide levels and a corresponding elevation of cortisol in healthy subjects (Olumese and Oboh, 2016c). This study was carried out to determine the ability of the polyphenolic rich Beetroot juice (BRJ) to inhibit the key enzymes a-amylase and a-glucosidase linked to type 2 diabetes.

\section{MATERIALS AND METHODS}

\section{Sample Collection and Treatment}

Beetroot (Beta vulgaris) was obtained from a vegetable market, Airport road, Benin City, Nigeria. The plant was identified by a 
Taxonomist at the Department of Plant Biology and Biotechnology at the University of Benin with a voucher number $\mathrm{UBH}_{B} 374$ deposited in the Herbarium. The dark red bulbous roots of the beetroots were rinsed with distilled water, $10 \mathrm{~kg}$ of beetroot was peeled and blended with three litres (3L) of distilled water in a Moulinex Blender LM 2411, Wanette, Oklahoma, USA. The juice was filtered using a muslin cloth, allowed to settle for 20-30 minutes. The filtrate obtained was then freeze dried [Armfield vacuum freeze dryer Model FT 33, England]. The freeze-dried sample was stored at $0{ }^{\circ} \mathrm{C}$ until ready for use.

\section{Chemicals and Reagents}

The enzyme porcine a-amylase [ EC 3.2.1] and a-glucosidase [ EC 3.2.1.20] were obtained from Sigma-Aldrich chemie GmbH (Steinheim, Germany) and Sigma-Aldrich (St. Louis, MO, USA).

\section{Sample Preparation}

One gramme $(1 \mathrm{~g})$ of the freeze-dried extract of the beetroot (Beta vulgaris) was dissolved in 25 $\mathrm{ml}$ of distilled water in a beaker and left to stand for 24 hours in a covered container. A $1 \%$ starch solution was prepared by dissolving $1 \mathrm{~g}$ soluble starch in an initial volume of $80 \mathrm{ml}$ of $0.02 \mathrm{M}$ sodium phosphate buffer, $\mathrm{pH}$ 6.9. The solution was allowed to boil while stirring. Thereafter, the temperature was maintained below boiling point for 15 minutes to solubilise the starch solution and allowed to cool to room temperature. The total volume was then made up to $100 \mathrm{ml}$ by adding distilled water.

\section{Enzyme Assay \\ Alpha-glucosidase inhibition assay}

a-glucosidase activity was determined by the modified method described by Oboh et al. (2012). Appropriate dilutions of the extracts (0, $50,100,150,200 \mu \mathrm{L}$ ) of the beetroot extract representing $0.8 \mathrm{mg} / \mathrm{ml}, 1.6 \mathrm{mg} / \mathrm{ml}, 2.4 \mathrm{mg} / \mathrm{ml}$ and $3.2 \mathrm{mg} / \mathrm{ml}$ were mixed with $100 \mu \mathrm{L}$ of $\alpha$ glucosidase (EC 3.2.1.20) solution $(1.0 \mathrm{U} / \mathrm{mL})$ in $0.1 \mathrm{mM}$ phosphate buffer $(\mathrm{pH}$ 6.9) respectively and incubated at $25^{\circ} \mathrm{C}$ for 10 minutes. Then, $50 \mu \mathrm{L}$ of $5 \mathrm{mM} \mathrm{p}$-nitrophenyl- $\mathrm{\alpha}-$
D-glucopyranoside solution in $0.1 \mathrm{mM}$ phosphate buffer ( $\mathrm{pH} \mathrm{6.9)}$ was added. The mixture was incubated at $25^{\circ} \mathrm{C}$ for 5 minutes, absorbance was read at $405 \mathrm{~nm}$. The aglucosidase inhibitory activity was expressed as percentage inhibition calculated using the formula:

$\%$ of inhibition = (Absorbance of control Absorbance of sample)/Absorbance of control $x$ 100

\section{Alpha-amylase inhibition assay}

a-amylase activity was determined by the method described by Worthington (1993a). Appropriate dilutions of the beetroot extracts $(0$, $50,100,150,200 \mu \mathrm{L}$ ) representing $0.8 \mathrm{mg} / \mathrm{ml}$, $1.6 \mathrm{mg} / \mathrm{ml}, 2.4 \mathrm{mg} / \mathrm{ml}$ and $3.2 \mathrm{mg} / \mathrm{ml}$ of the beetroot extracts were mixed with $500 \mu \mathrm{L}$ of $0.02 \mathrm{M}$ Sodium Phosphate Buffer ( $\mathrm{pH} 6.9$ with $0.006 \mathrm{M} \mathrm{NaCl}$ ) containing porcine pancreatic amylase [EC 3.2.1.1] [0.5 mg/ml] and then incubated at $25^{\circ} \mathrm{C}$ for 10 minutes. Then $500 \mu \mathrm{l}$ of $1 \%$ starch solution in $0.02 \mathrm{M}$ sodium phosphate buffer (pH 6.9 with $0.006 \mathrm{M} \mathrm{NaCl})$ was added to the reaction mixture in the test tubes respectively. The reaction mixture was incubated at $25^{\circ} \mathrm{C}$ for 10 minutes and stopped with $1.0 \mathrm{ml}$ of dinitrosalicylic acid (DNSA) colour reagent, followed by incubation in boiling water $\left(100{ }^{\circ} \mathrm{C}\right)$ for 5 minutes and allowed to cool at room temperature. The reaction mixture was diluted by adding $2.5 \mathrm{ml}$ of distilled water.

The control included all other reagents and the enzyme except for the test sample. Acarbose was used as a positive control. The mixtures were incubated at $25^{\circ} \mathrm{C}$ for 5 minutes, before reading the absorbance at $540 \mathrm{~nm}$ in the spectrophotometer.

The percentage of amylase inhibition by the extract was subsequently calculated as follows: $\%$ of inhibition = (Absorbance of control Absorbance of sample)/Absorbance of control $x$ 100 


\section{Data analysis}

The graph of \% enzyme inhibition was plotted against extract concentration. $I_{50}$ is the concentration needed to inhibit $50 \%$ of the enzyme activity (a-glucosidase and a-amylase) under the described assay conditions. This was calculated using graph pad prism version 6.1 for windows.

\section{RESULTS}

\section{Enzyme inhibition assay}

This study showed that beetroot juice inhibited the activities of $\alpha$-glucosidase and $\alpha$-amylase in a dose-dependent manner. Figure 1 shows the different doses of beetroot juice $0.8 \mathrm{mg} / \mathrm{ml}, 1.6$ $\mathrm{mg} / \mathrm{ml}, \quad 2.4 \mathrm{mg} / \mathrm{ml}$ and $3.2 \mathrm{mg} / \mathrm{ml}$ gave a percentage inhibition of a-glucosidase of 53.5 $\%, 61.7 \%, 73 \%, 85.25 \%$ respectively. The half maximal inhibitory concentration $\left(\mathrm{IC}_{50}\right)$ that is capable of inhibiting $50 \%$ of the enzyme activity was found to be $0.77 \mathrm{mg} / \mathrm{ml}$ of the extract.

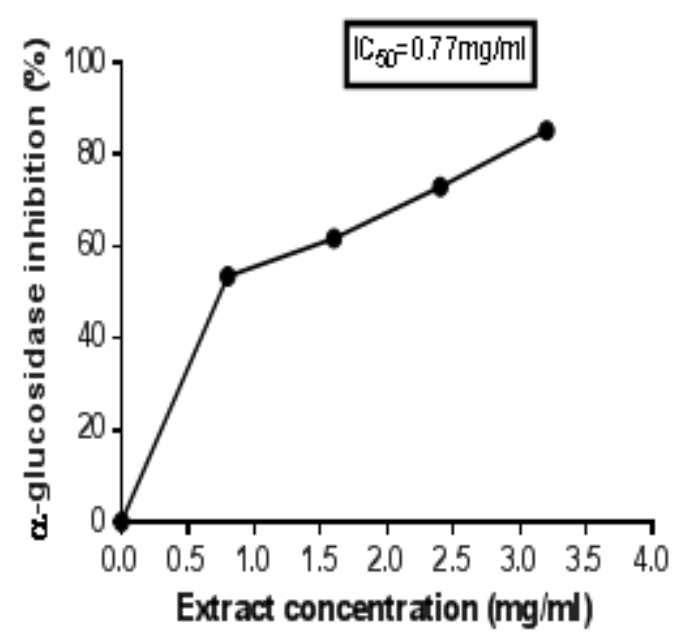

Figure 1: Beetroot juice inhibitory activity on aglucosidase invitro

a-amylase inhibition studies (Figure 2) revealed that the different concentration of beetroot extract $0.8 \mathrm{mg} / \mathrm{ml}, 1.6 \mathrm{mg} / \mathrm{ml}, 2.4 \mathrm{mg} / \mathrm{ml}$ and 3.2 $\mathrm{mg} / \mathrm{ml}$ gave a percentage inhibition of $26.22 \%$, $41.60 \%, 59.44 \%$ and $73.42 \%$ respectively. The $\mathrm{IC}_{50}$ for inhibition of a-amylase was determined to be $1.78 \mathrm{mg} / \mathrm{ml}$.

Acarbose $(0.08 \mathrm{mg} / \mathrm{ml})$ which was used as a positive control had $\mathrm{IC}_{50} 0.22 \mathrm{mg} / \mathrm{mL}$ and 0.18 $\mathrm{mg} / \mathrm{mL}$ respectively for a-glucosidase and $\mathrm{a}$ amylase (Figures 3 and 4)The in vitro inhibitory effect of acarbose on a-glucosidase and aamylase were observed to be higher when compared to beetroot aqueous extract

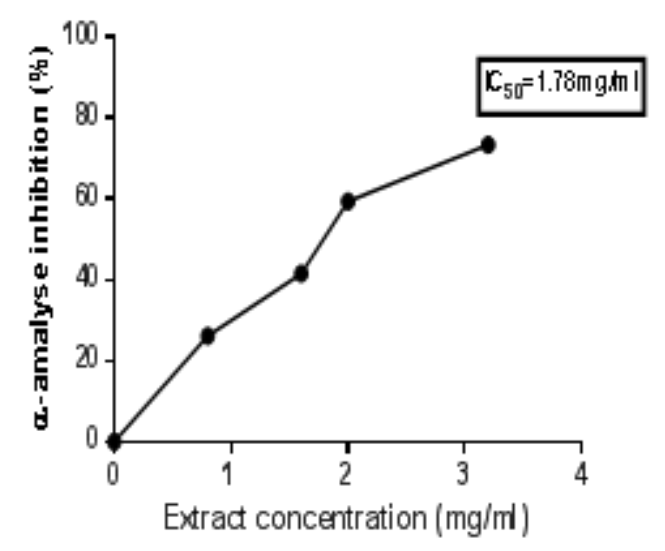

Figure 2: Beetroot juice inhibitory activity on aamylase in vitro

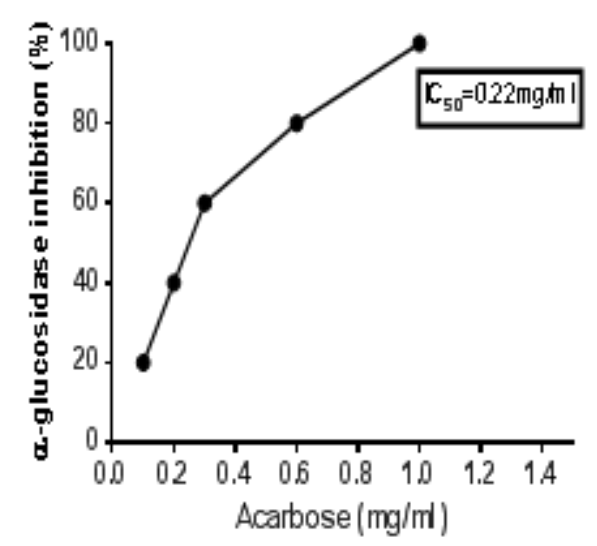

Figure 3: Acarbose inhibitory activity on a-glucosidase in vitro

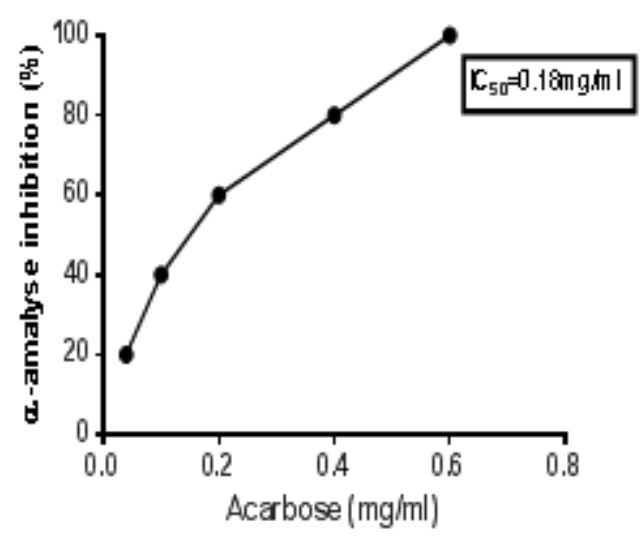

Figure 4: Acarbose inhibitory activity on aamylase in vitro 


\section{DISCUSSION}

Research have shown that substances that inhibit key enzymes such as a-amylase and aglucosidase in the digestion of carbohydrates (starch blockers) are important, as they can be used in the management of type 2 diabetes (McCue et al., 2005; Adefegha and Oboh, 2013). The inhibition of these enzymes by these starch blockers slow down the digestion of carbohydrates and consequently slow down the absorption of glucose from the gut into the blood stream (Kwon et al., 2006; Oboh et al., 2010). This delays a sharp rise in postprandial blood glucose following a carbohydrate meal. Many drugs used in the management T2D such as acarbose act through this mechanism. Bioactive compounds from natural sources with the potential to inhibit these key enzymes involved in the digestion of carbohydrates may be relatively cost effective and probably less toxic when compared to synthetic starch blockers (Adefegha and Oboh, 2013). Moreover, these bioactive compounds from food sources may act synergistically in the management and possible prevention of type 2 diabetes.

This study showed beetroot juice inhibited aamylase within the range of $26 \%-73 \%$ in a dose dependent manner, with an $\mathrm{IC}_{50}$ of $1.78 \mathrm{mg} / \mathrm{mL}$. Similarly, a-glucosidase was inhibited in the range $53 \%-85 \%, I C_{50}=0.77 \mathrm{mg} / \mathrm{mL}$. Studies by Nwanna et al. (2013) using methanolic extracts of eggplant S. marcocarpon and S. melongena were seen to inhibit a-amylase and aglucosidase in a dose dependent manner. However, this current study revealed that the inhibition of these enzymes by beetroot aqueous extract was slightly lower than that of acarbose $(0.08 \mathrm{mg} / \mathrm{ml})$ which was used as the positive control and inhibited a-amylase with $\mathrm{IC}_{50}=0.18 \mathrm{mg} / \mathrm{mL}$ and $\mathrm{a}$-glucosidase with $\mathrm{IC}_{50}=$ $0.22 \mathrm{mg} / \mathrm{mL}$. The inhibition by beetroot juice is stronger for a-glucosidase and the $\mathrm{IC}_{50}$ for this inhibition is relatively close to that of acarbose. This agrees with researches done by Adefegha and Oboh (2013), Thilagam et al. (2013) in which plant extracts showed a stronger inhibition of a-glucosidase when compared to the inhibition of $a$-amylase.

Beetroots have been shown to be rich in polyphenol content and other bioactives such as flavonoids, betalains and ascorbic acid (Murthy and Manchali, 2013; Olumese and Oboh, 2016b). Several studies have correlated a-amylase and a-glucosidase inhibition by plant extract to their polyphenol content (McCue et al., 2004; Husni et al., 2014; Lim and Loh, 2016; Wang et al., 2016). Reports on the mechanism by which this inhibition is achieved is varied. McCue et al. (2004) suggested that amylase inhibition may be due to the disruption of disulphide bridges on the surface of the enzyme by polyphenols, however the inhibition of a-glucosidase may be through other mechanisms. Other studies report that the mechanisms of these inhibitions may be competitive, non-competitive or mixed competition (Kazeem et al., 2013; Wang et al., 2016). Nevertheless, the mechanism through which these plant bioactives inhibit these enzymes may be through a synergy of mechanisms. The inhibition of a-amylase and a-glucosidase by aqueous beetroot juice in this study might follow the same mechanisms by polyphenols, moreover, juicing causes more polyphenol to be released through rupturing of the cell membrane, thus making them available (Olumese and Oboh, 2016b). Studies suggest that aqueous extract are relatively stronger inhibitors of these enzymes than other extracts (Kazeem et al., 2013).

\section{CONCLUSION}

In this study, it was found that beetroot aqueous extract inhibits the carbohydrate hydrolyzing enzymes a-amylase and a-glucosidase in vitro in a dose dependent manner. This inhibition could promote gradual release of glucose into blood postprandial which could be effective in the management of type 2 diabetes.

\section{ACKNOWLEDGEMENT}

The authors would like to acknowledge Professor G. Oboh and other members of the Functional foods and Nutraceutical unit, 
Department of Biochemistry, Federal University of Technology, Akure for the availability of their facility during this study.

\section{CONFLICTS OF INTEREST AND OTHER DISCLOSURES}

The authors have no conflict of interest related to this study.

\section{REFERENCES}

Adefegha, S.A. and Oboh, G. (2013). Phytochemistry and mode of action of some tropical spices in the management of type-2 diabetes and hypertension. African Journal of Pharmacy and Pharmacology, 7 (7): 332-346.

Ansari, R., Singh, S.B., Kumar, P. and Broadway, A.A. (2017). Proximate and sensory analysis of beetroot (Beta vulgaris) and Jamun (Syzygium cumini) juice blended drink. Journal of Pharmacognosy and Phytochemistry, 6(6): 1280-1283.

Bahadoran, Z., Mirmiran, P., and Azizi, F. (2013). Dietary polyphenols as potential nutraceuticals in management of diabetes: a review. Journal of Diabetes and Metabolic Disorders, 12, 43. Available from: http://doi.org/10.1186/2251-6581-1243.

Chawla, H., Parle, M., Sharma, K., Yadav, M., (2015). Beetroot: A Health Promoting Functional Food. Inventi Rapid: Nutraceuticals, 2016(1):1-5.

Dragan, S., Andrica, F., Serban, M.C. and Timar, R. (2015). Polyphenols-rich natural products for treatment of diabetes. Current Medicinal Chemistry, 22(1):14-22.

Georgiev, V.G., Weber, J., Kneschke, E.M., Denev, P.N., Bley, T. and Pavlov, A.I. (2010). Antioxidant activity and phenolic content of betalain extracts from intact plants and hairy root cultures of the red beetroot Beta vulgaris cv. Detroit dark red. Plant Foods for Human Nutrition, 65(2):10511.
Husni, A., Wijayanti, R. and Ustadi. (2014). Inhibitory Activity of a-Amylase and aGlucosidase by Padina pavonica Extracts. Journal of Biological Sciences, 14: 515-520.

Kazeem, M. I., Adamson, J. O., and Ogunwande, I. A. (2013). Modes of Inhibition of a-Amylase and aGlucosidase by Aqueous Extract of Morinda lucida Benth Leaf. BioMed Research International, 2013, 527570.

Kwon, Y.I., Jang, H.D. and Shetty, K. (2006). Evaluation of Rhodiola crenulata and Rhodiola rosea for management of type II diabetes and hypertension. Asia Pacific Journal of Clinical Nutrition, 15:425-432.

Lim, S.M. and Loh SP. (2016). In vitro antioxidant capacities and antidiabetic properties of phenolic extracts from selected citrus peels. International Food Research Journal. 23(1):211219.

Lintas, C. (1992). Nutritional aspects of fruits and Vegetable Consumption. Options Mediterraennes, 19: 79-8.

McCue, P., Kwon, Y.I. and Shetty, K. (2005). Anti-diabetic and anti-hypertensive potential of sprouted and solid-state bioprocessed soybean. Asia Pacific Journal of Clinical Nutrition, 14:145152.

McCue, P., Vattem, D. and Shetty, K. (2004). Inhibitory effect of clonal oregano extracts against porcine pancreatic amylase in vitro. Asia Pacific Journal of Clinical Nutrition. 13(4): 401-408.

Murthy K.N.C., Manchali S. (2013). Antidiabetic Potentials of Red Beet Pigments and Other Constituents. In: Neelwarne B. (eds) Red Beet Biotechnology. Springer, Boston, MA, Pp 155-174.

Nwanna, E.E., Ibukun, E.O. and Oboh, G. (2013). Inhibitory effects of methanolic extracts of two eggplant species from South-western Nigeria on starch hydrolysing enzymes linked to type-2 diabetes. African Journal of Pharmacy and Pharmacology, 7(23):1575- 1584. 
Oboh, G., Akinyemi, A. J., \& Ademiluyi, A. O. (2012). Antioxidant Properties and Inhibitory Effect of Ethanolic Extract of Struchium Sparganophora (Ewuro Odo) Leaf on a - Amylase and aGlucosidase Activities. African Journal of Traditional, Complementary, and Alternative Medicines, 9(3), 342-349.

Oboh, G., Akinyemi, J.A., Ademiluyi, A.O. and Adefegha, S.A. (2010). Inhibitory effect of aqueous extract of two varieties of Ginger on Key Enzymes linked with Type-2 Diabetes. Journal of food and nutrition research. 49(1):14-20.

Odoh, U. E. and E. C. Okoro, 2013. Quantitative Phytochemical, Proximate/Nutritive Composition Analysis of Beta vulgaris Linnaeus (Chenopodiaceae). International Journal of Current Research, 5: 37233728.

Olumese, F.E. and Oboh, H.A. (2016a). Mineral content of raw and processed Beetroot (Beta vulgaris) gown in Nigeria. Nigerian Journal of Applied Science, 34:208-216.

Olumese, F.E. Oboh, H.A. (2016b). Antioxidant and Antioxidant capacity of raw and processed Nigerian Beetroot (Beta vulgaris). Nigerian Journal of Basic and Applied Science, 24(1), 35-40.

Olumese, F.E. and Oboh, H.A. (2016c). Effects of daily intake of beetroot juice on blood glucose and hormones in young healthy subjects. Nigerian quarterly journal of hospital medicine, 26(2): 455462.

Pitalua, E., Jimenez, M., Vernon-Carter, E.J. and Beristain, C.I. (2010). Antioxidative activity of microcapsules with beetroot juice using gum Arabic as wall material. Food and Bioproducts processing, 88(2-3):253-258.

Thakur, V. and Das Gupta, D.K. (2006). Studies on the clarification and concentration of beetroot juice. Journal of food processing and preservation, $30(2)$ : 194-207.
Thilagam, E., Parimaladevi, B., Kumarappan, C. and Mandal, S.C. (2013). aGlucosidase and a-Amylase Inhibitory Activity of Senna surattensis. Journal of Acupuncture and Meridian Studies. 6(1):24-30.

Vinayagam, R.., Jayachandran, M. and Xu, B. (2016). Antidiabetic Effects of Simple Phenolic Acids: A Comprehensive Review. Phytotherapy Research, 30(2):184-99.

Wang, W., Xu, H., Chen, H., Tai, K., Liu, F. and Gao, Y. (2016). In vitro antioxidant, anti-diabetic and antilipemic potentials of quercetagetin extracted from marigold (Tagetes erecta L.) inflorescence residues. Journal of Food Science and Technology, 53(6):261424.

Wootton-Beard, P. C., Brandt, K., Fell, D., Warner, S., \& Ryan, L. (2014). Effects of a beetroot juice with high neobetanin content on the early-phase insulin response in healthy volunteers. Journal of Nutritional Science, 3, e9. Available from: http://doi.org/10.1017/jns.2014.7

Worthington, V., (1993a.) Alpha amylase. In Worthington Enzyme Manual: Worthington Biochemical Corp. Freehold, NJ., pp: 36-41. 